\title{
4
}

\section{Why Purpose Needs Strategy (and Vice Versa)}

\author{
Carlos Rey and Joan E. Ricart
}

An independent director once had to deal with a conflict on his board when a strategy consultant presented a report after three months of intensive analysis. According to the consultant, the only feasible scenario was to abandon the company's main customer base and move into a new market segment altogether. This would entail considerable downsizing of the company. The report was based on a thorough and consistent analysis of the company's market share distribution, as well as, demographic trends, economies of scale, and many other statistics. The report was impeccable. It was so well argued and supported by data that it seemed impossible that anything other than the consultant's proposal would be considered. However, none of it made sense to the $\boldsymbol{C E O}$. His main argument was emphatic: "I don't see how we can do this. Moving to this new market segment is a big leap from our traditional business. We've successfully run this company for over 20 years, and we've always known where to focus our efforts. This proposal doesn't fit

at all with the idea that I have for this business. I'm not completely against downsizing if strictly necessary, but moving into this new segment? Sorry guys, I simply don't see it."

\footnotetext{
C. Rey $(\bowtie)$

Universitat Internacional de Catalunya, Barcelona, Spain

e-mail: carlosrey@uic.es
}

J. E. Ricart

Strategic Management Department, IESE Business School, Barcelona, Spain e-mail: JERicart@iese.edu 
Next, the president took the floor: "We cannot accept this under any circumstance. We must remain faithful to the values that have been the beacon of this company for years. Consultants need to understand that we are a familyowned company, not a public company that looks only to maximizing profits. The best thing to do is to stay true to ourselves and do the right thing. The consultant's advice for us to fire employees would entail the opposite."

When he got home, the independent director reviewed his notes and became more and more concerned. The next board meeting would be held in three days and he needed something more concrete to propose. Each member had his own arguments, and he could not see how to frame a plausible course of action. He left his notes and took a deep breath while asking himself: "So, who's right?"

Despite decades of research on strategy, "we still know little about what strategy means to actual strategists and how they use it in practice." 1 Indeed, there is an increasing concern that most management theories are not relevant to practice because they are unable to capture the "logic of practice." In the real world, organizations rarely embrace a single logic. Both organizations and individuals face and maintain coexisting multiple logic that "may or may not be mutually compatible." ${ }^{3}$

This pluralistic view of strategy can be explained by what we call the multilogic of strategy. The strategic logic is a set of macro-level beliefs and schemas that strongly influence both strategic theory and practice, and refer to assumptions about the nature of strategic choices. As the concept of strategy has the potential to help us explain "how the relationship between managerial cognition and managerial practice leads to organizational outcomes,"4 the concept of strategic logic helps us to understand how different kinds of logic may affect how managers understand strategy.

At the intersection of cognitive and strategic management theories, we identify three salient sources of strategic logic — the analytical, business model, and institutional perspectives, each one forming a different perspective of strategy (see Table 4.1). The first entails the procedures used by managers to understand reality, the second has to do with business model creation and development, and the third is related to the role of companies in society and their business environment.

Table 4.1 Analytical, business model, and institutional perspectives

\begin{tabular}{ll}
\hline Strategic perspectives & Description \\
\hline Analytical & Reasoning based on analytical procedures \\
Business model & Holistic conceptualization of the business model \\
Institutional & Reasoning based on social and cultural influences \\
\hline
\end{tabular}




\section{Analytical Perspective}

This strategic perspective is related to the analytical logic present in strategic reasoning and procedures. The literature on business strategy is full of examples of how managers make use of analytical logic, traditionally considered a cornerstone of strategic development. This logic includes, for instance, deduction, ${ }^{5}$ induction, ${ }^{6}$ prediction, ${ }^{7}$ causation, ${ }^{8}$ and effectuation logic. ${ }^{9}$ By using and combining different analytical logic, strategists can evaluate alternatives, variables, indicators, and objectives in order to establish a course of action toward their desired results.

In the example we used at the beginning of this chapter, analytical logic represented the approach of the consultant, "following numbers and market estimations." Through analytical logic, strategists gain a better understanding of situations to obtain further explanations and conclusions. ${ }^{10}$ Based on this idea, analytical perspective represents the use of procedures strategists employ as resources for understanding reality. As analytical logic is based on explicit information, it uses empirical evidence and predictions to reach conclusions. In other words, the analytical perspective reflects how strategists make use of different tools, techniques, and frameworks to make strategic choices.

\section{Business Model Perspective}

This perspective is based on the logic that allows us to conceptualize business models, initially identified as the dominant logic. ${ }^{11}$ Dominant logic is the conceptualization of the business model stored as a shared cognitive map-or a set of schemas-among the dominant coalition (board of directors, management team). In other words, it is the understanding of how the business works in a particular company. It acts as a filter and enables us to process large amounts of information ${ }^{12}$ and manage complex strategic issues. ${ }^{13}$ The concept of dominant logic, initially identified as something unfinished and highly plastic, ${ }^{14}$ later expanded its scope to encompass specific dimensions of value creation. These are, for example, value creation logic, ${ }^{15}$ service logic innovation, ${ }^{16}$ the logic of organizational boundaries, ${ }^{17}$ and the logic of exchange. ${ }^{18}$

Business model logic is related to intuition, born of experience, and therefore it allows strategists to "see" solutions and opportunities beyond analytical data and procedures. Thus, business model logic requires a profound knowl- 
edge of reality that permits us to establish valid hypotheses regarding the fundamental aspects of a given business model. As business models reflect choices and their consequences, ${ }^{19}$ this logic helps us to understand the key strategic choices informing the business. In the tale told at the beginning of this chapter, the logic of the CEO was grounded in business model logic ("I simply do not see it"). Confronted with particular situations, the business model perspective does not rely on data and analysis alone, but on the holistic representation of reality. We see this, for example, when managers pay attention to and interpreting the value creation of other companies, or experiment with value creation alternatives, or simply look beyond their existing industry and geographical borders.

\section{Institutional Perspective}

This perspective comes from the intersection of the literature on strategic management and institutionalism. Institutional logic represents the role of contingent sets of social norms and principles that shape individual and organizational behavior in the search for appropriateness. ${ }^{20}$ "As people go through their lives, they are constantly working with, for and against multiple forms of institutional logic that shape their social and cultural contexts." ${ }^{21}$ In other words, they represent the way society and business influence thinking inside the organization. There are several forms of institutional logic seen in business today such as: commercial logic, ${ }^{22}$ financial logic, ${ }^{23}$ social welfare logic, ${ }^{24}$ environmental logic, ${ }^{25}$ or family logic. ${ }^{26}$ They shape the practice in firms when they are represented in the organization by individuals who have a cognitive and motivational affinity for them. ${ }^{27}$ These individuals become "carriers" of institutional logic. ${ }^{28}$ For example, salespersons can be carriers of commercial logic, controllers can be carriers of the financial logic, HR executives can be carriers of social welfare logic, and board family members can be carriers of the family logic.

In the story at the beginning of this chapter, the president's reasoning represents the institutional perspective ("we are a family-owned company, not a public company that looks only to maximizing profits"). Under this logic, strategists base their choices on the identity of the organization relative to what is legitimate and appropriate. The institutional logic helps managers to identify the right principles of the company and to recognize when they should evolve. The articulation of institutional logic into strategy can be developed through narratives, and other symbolic means, in ways that allow 
companies to manage the degree to which institutional logic becomes both accessible and active.

\section{Purpose and Profit}

Multi-logic approaches can be a source of enrichment for the overall strategy. However, they can be a source of conflict as well. As we have seen in our initial story, different forms of logic can lead to a situation of paralysis, instead of helping the company move forward. The fundamental problem is not the presence of different logic, but rather the lack of a focal point helping to integrate the different perspectives.

Over decades, academics have suggested that profit maximization is the overarching principle informing our logic of strategy. Under this theoretical view, analytical logic should serve the strategies that lead to profit maximization. Business model logic should aim to maximize economic value and institutional logic should be managed in such a way that allows organizations to obtain the maximum profit possible from their institutional environment.

But reality is quite distant from this. We can compare this with what, for centuries, was a wrong but somehow useful theory of the universe: the geocentric view of the cosmos. In ancient times, people believed that the earth was the center of the universe and the sun and all the stars revolved around it. Despite this being wrong, it was still a "somehow useful" explanation that helped to establish calendar calculations and astronomical charts for over 1500 years. Discordant heliocentric voices like that of Aristarco de Samos in the second century were not given much attention. Against those who challenged the heliocentric view, both moral and religious arguments were used (e.g. as with the excommunication of Galileo). The reason why geocentric views prevailed for centuries is that heliocentric predictions were not better, as a practical matter, than geocentric ones. It was not until the universal gravitation theory of Newton that the heliocentric theory definitely triumphed over the geocentric one. From then on, the geocentric theory became a "no longer useful" theory.

Something similar is happening with the view that profit maximization should be the only consideration for businesses. Despite being distant from reality — as we have known for more than 40 years ${ }^{29}$ — this view has prevailed for decades because alternative theories did not provide better estimations (e.g. contradicting research on Corporate Social Responsibility (CSR) and 
performance $\left.{ }^{30}\right)$. Many purpose-driven leaders have strongly contested the profit maximization theorists with purpose-driven theories-for example, David Packard, $1960^{31}$ — but their proposals were not given much attention in strategic theory. Purpose-driven theories were contested with categorical arguments-for example, by Milton Friedman. ${ }^{32}$ It was not until prosocial motivation theories were accepted-demonstrating that individuals and organizations have social motivations beyond maximizing profits- that purposedriven theories started to be accepted. ${ }^{33}$

This process has been accelerated by the dramatic 2008 financial crisis that helped us to recognize that the wrong but "somehow useful" theory of profit maximization was no longer useful, but actually harmful. Consider, for example, the conclusion of researchers on how Sephora, Four Seasons, and Danone US quickly recovered from the decline in profits they endured at the beginning of the financial crisis. How did they do it? Instead of focusing on one goal only, such as profits, their employees collaborated to shape a collective purpose, "that superseded individual goals and accounted for the key elements required to achieve and sustain excellence." ${ }^{34}$ Another example is the case of the Swedish bank Handelsbanken that enjoyed continuous growth in profitability during the financial crisis. With no emphasis on maximizing returns but, instead, with a customer-centric purpose, "the goals were simply to track a moving target by always having higher customer satisfaction and profitability than a weighted average of the competition." 35 These examples, and many others, show that purpose does not mean giving up striving for excellent economic results. It requires combining purpose and profit.

We can see this, for example, in the main strategic handbooks, where the latest editions have reviewed the profit maximization dogmas elucidated in earlier editions. ${ }^{36}$ Or in the vast majority of the new frameworks for strategy-for example, blue ocean, lean, agile-where purpose is placed at the very core of strategy. We believe Larry Fink, the CEO of BlackRock, the largest investment firm in the world, set the example when he demanded companies in which his firm invests to embrace a social purpose, stating: "every company must not only deliver financial performance, but also show how it makes a positive contribution to society." 37 This reflects a growing awareness of our current reality. Purpose is not only the result of psychological forces but also, and with the same intensity, the result of social and economic pressures. 


\section{Coupling Strategy with Purpose}

Since Bartlett and Ghoshal first made their proposal in 1993 to shift from strategy to purpose, ${ }^{38}$ many strategists have been won over to the idea. As we see it, the fundamental question is not choosing between purpose and strategy but instead putting purpose at the center of strategy. In this sense, we believe purpose should be infused with multi-logic strategy and vice versa. While purpose should not be considered a strategy, purpose requires strategy.

Every strategic logic we have seen provides a fundamental contribution to the development of purpose in the organization. The various forms of strategic logic contribute to purpose development in the following areas: analytical coupling, business model coupling, and institutional coupling.

Analytical coupling is related to the way purpose become concrete in plans and objectives that express the dynamism of purpose in practice. In this vein, purpose plays the role of an overarching constraint that helps managers maintain a firm focus on purpose, while concentrating their efforts on activities such as strategic analysis, planning, and implementation. One illustration of this can be seen in Google. The dexterity Google exhibits in big data and analytical tools helps them decide which products move forward and which are discontinued. This is in direct relation to the company's purpose, which is to "organize the world's information and make it universally accessible and useful." This coupling between analytical logic and purpose can be developed by different means. There is, for example, the practice of putting the purpose at the very beginning of any strategic initiative, or using purpose-driven indicators to evaluate how well the organization is fulfilling its purpose.

Business model coupling regards the way value creation strategies and business models are conceptualized under the framework of purpose. By imbedding purpose in business models, it helps purpose sustainability, eliminating potential conflicts between purpose and profit. This is the approach, for example, of shared value, the concept that calls companies to establish their business model around the intersection of business interests and social needs. ${ }^{39}$ This is also referred to as "massive transformative purpose," a common trait found in the fastest growing startups of the world like TED or Singularity University. ${ }^{40}$ From this perspective, purpose is not only a constraint but also a source of opportunity. Such is the case for IKEA, a pioneer in configurating its business model consistent to its purpose of "creating a better everyday life for the many." The coupling between purpose and business models can be reinforced by practices such as 
Table 4.2 The three strategic perspectives integrated with purpose

\begin{tabular}{lll}
\hline Perspectives & Purpose as & Examples \\
\hline Analytical & Constraint & $\begin{array}{l}\text { Purpose as a filter for strategic decision-making } \\
\text { Purpose-driven indicators } \\
\text { Business model }\end{array}$ \\
$\begin{array}{ll}\text { Opportunity } \\
\text { Shared valueBrand purpose } \\
\text { Legitimacy }\end{array}$ & $\begin{array}{l}\text { Institutional framing } \\
\text { Stakeholder management }\end{array}$ \\
\hline
\end{tabular}

purpose-driven innovation or brand purpose, which help businesses to evolve and reconfigure themselves around the fulfillment of purpose.

Institutional coupling is related to the way organizations develop institutional principles and values with regard to organizational purpose. It offers companies the ability to both maintain equilibrium between the company and its stakeholders as well as provide organizational members a source of higher meaning and motivation. We see a great example of this in Johnson $\&$ Johnson's credo, which has served the company for decades as a beacon by establishing its relationship between stakeholders and company members. By connecting purpose and institutional logic, strategists tap into a deeper source of motivation, as "one of the most effective ways to influence behavior is to influence [a person's] identification with a given logic and its associated practices." ${ }^{41}$ In this regard, purpose acts as a source of legitimacy, guiding strategy by the primary principle of acting accordingly to "who you are." This can be promoted by practices such as institutional framing (missions, values, principles) or stakeholder management, where a company preserves purpose through the evolution and reconfiguration of its institutional environment (Table 4.2).

\section{Integrating of the Three Perspectives}

Beyond the specific contribution of each perspective, their highest potential comes by combining the three forms of logic with purpose simultaneously. Take for example the cases of Google, IKEA, and Johnson \& Johnson, they demonstrate that success does not come from one perspective of logic alone, but from integrating purpose with all three. In the case of Google, analytical dexterity shows an outstanding fit between purpose and business model innovation, while also winning admiration and legitimacy in social arenas. Consider also the lessons that Yoffie and Cusumano derived from the study of Steve Jobs, Bill Gates, and Andy Grove. ${ }^{42}$ The way in which their strategies were built is a good illustration of how the three forms of logic guide their decisions (e.g. dexterity in analysis, synthesis of information, big picture 
vision, and using guiding principles to generate game-changing business models).

This approach is consistent with literature that recognizes the multiplicity of logic as a source of strategic heterogeneity and innovation that help strategists develop more consistent purpose-driven strategies. ${ }^{43}$ In this view, beyond the salient logic related to individual characteristics, such as an individual's role in the organization, motivational affinity, or institutional biography, ${ }^{44}$ purpose-driven strategies call for the combination of each perspective in a harmonious way. From a practical perspective, integrating each logic with purpose can be done by using what we call integrated tools. These are combinations of existing models-for example, SWOT analysis, Porter's five forces, business model canvas, balanced scorecard-that form new tools and stimulate the integration of each strategic perspective with purpose. ${ }^{45}$

An example of this and a very powerful tool is the Purpose Model Canvas. It is an integrated tool that we have used with much success in companies of different sectors and sizes, ranging from big multinational corporations to local medium-sized companies. The tool is based on a model developed by Casadesus-Ricart. ${ }^{46}$ This model, extensively explained in previous publications, ${ }^{47}$ links choices and consequences by arrows based on causality theories, enabling users to identify virtuous cycles - feedback loops that strengthen the business model at every iteration. Based on this, the purpose model canvas helps the user contemplate all strategic choices and consequences forming the business model (e.g. pricing, segmentation, cost efficiency, productivity, marketing, customer service, innovation, recruitment). Then it considers the institutional principles of the company-its values, missions, policies, fundamental beliefs.

Once it has identified the key institutional and business model choices and their consequences, the user can identify whether a company's strategy is coherent enough to enhance purpose fulfillment in these four areas:

Alignment: refers to choices delivering consequences that move the organization toward fulfilling its stated purpose in that it helps to clarify which decisions fit (and which do not) into the organization's purpose.

Reinforcement: refers to choices that complement each other in the fulfillment of purpose. It takes the best from the existing capabilities to create synergies that amplify the impact of purpose.

Virtuousness: refers to virtuous circles, the feedback loops between choices and consequences, that help purpose to gain strength over time. Virtuousness is like the internal engine of purpose. It pushes purpose forward in every 
interaction and is the key distinguisher between great and mediocre purpose impact.

Sustainability: refers to the ability to sustain purpose fulfillment over time. It considers the challenges facing purpose that come from the competitive capacities of the business itself (e.g. imitation, substitution) or from the institutional environment (e.g., social shifts, reputation).

Finally, for each criterion, the model deploys analytical logic through indicators that evaluate various key aspects of the model (e.g. reinforcements between choices or virtuous circles). These indicators help to assess both how a company fulfills its purpose as well as the elements that fuel its fulfillment. In sum, the purpose model canvas helps us to see the connection between the "what," the "how," and the "why."

Figure 4.1 shows a simplified and basic example of the purpose model canvas, illustrating the reinforcement of each perspective. First, the business model is depicted by the company's key virtuous cycle (high volume, economies of scale, low cost, lost value) the key elements that reinforce it (low price reputation, supplier loyalty) and the overall result (high margins). Second, it shows how the institutional principles-environmental awareness, culture of service and cost consciousness-strengthen the virtuous cycle. Finally, it displays the key indicators (customer survey, gross yield per employee) that monitor alignment, reinforcement, virtuousness, and robustness of the whole model.

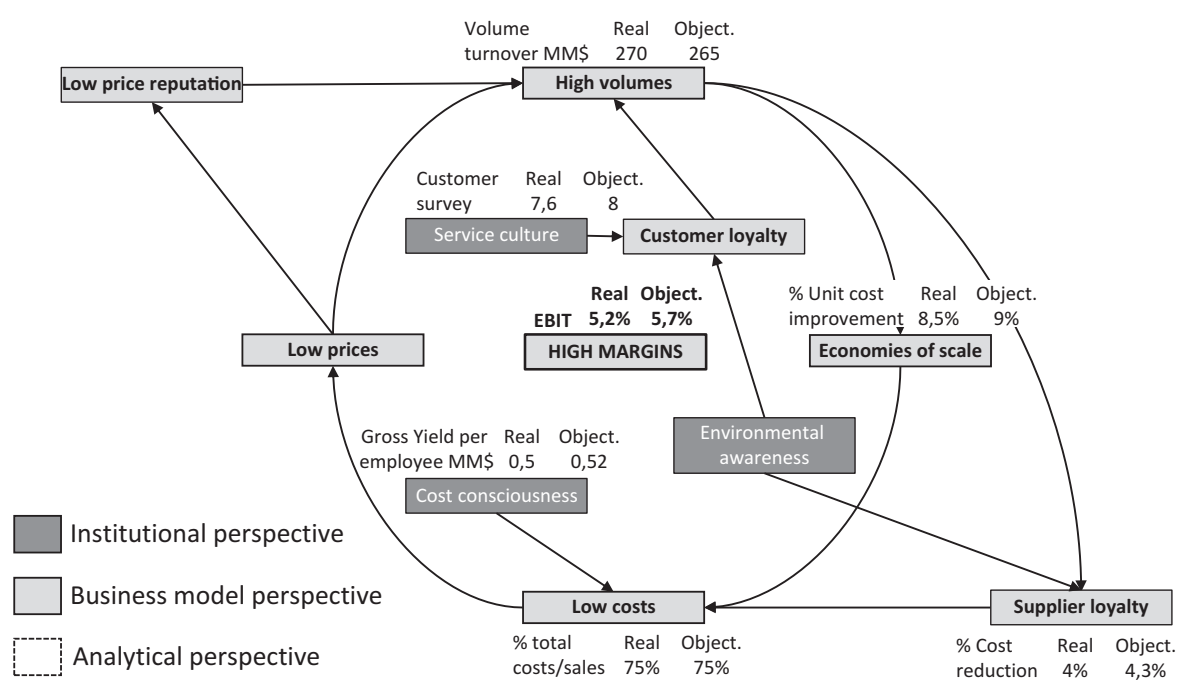

Fig. 4.1 Illustration of a "purpose model canvas" 
By using the purpose model canvas, we have seen how companies fuel strategy, reinforcing inspiration with analytical rigor over time. Indeed, this is the strategy we think best fits the example presented at the beginning of the chapter. More than simply coupling the logic of the consultant, president, and CEO with purpose, a purpose-driven strategy calls for jointly integrating each perspective with purpose, helping to establish a harmonious way forward.

\section{Notes}

1. Paroutis, S., \& Heracleous, L. (2013). Discourse revisited: Dimensions and employment of first-order strategy discourse during institutional adoption. Strategic Management Journal, 34(8), 935-956.

2. Sandberg, J., \& Tsoukas, H. (2011). Grasping the logic of practice: Theorizing through practical rationality. Academy of Management Review, 36(2), $338-360$.

3. Greenwood, R., Raynard, M., Kodeih, F., Micelotta, E. R., \& Lounsbury, M. (2011). Institutional complexity and organizational responses. Academy of Management Annals, 5(1), 317-371.

4. Paroutis, S., \& Heracleous, L. (2013). Discourse revisited: Dimensions and employment of first-order strategy discourse during institutional adoption. Strategic Management Journal, 34(8), 935-956.

5. Deduction logic: Reasoning that determines the validity of the conclusion if the premise of the rule is observed to be true. Dong, A., Garbuio, M., \& Lovallo, D. (2016). Generative sensing. California Management Review, 58(4), 97-117.

6. Induction logic: Reasoning based on a limited set of cases to establish a degree of empirical truth for a hypothesis. Ibidem.

7. Prediction logic: Takes the environment as outside the control of the decisionmaker, who therefore attempts to predict and adapt to changes in it. Read, S., Dew, N., Sarasvathy, S. D., Song, M., \& Wiltbank, R. (2009). Marketing under uncertainty: The logic of an effectual approach. Journal of Marketing, 73(3), 1-18.

8. Causation logic: Logical process that aims to reach a predefined goal. Sarasvathy, S. D. (2001). Causation and effectuation: Toward a theoretical shift from economic inevitability to entrepreneurial contingency. Academy of Management Review, 26(2), 243-263.

9. Effectuation logic: An inversion of predictive rationality in the creation of new firms, products, services, and markets. Ibidem.

10. Nadkarni, S., \& Barr, P. S. (2008). Environmental context, managerial cognition, and strategic action: An integrated view. Strategic Management Journal, 29(13), 1395-1427. 
11. Bettis, R. A., \& Prahalad, C. K. (1995). The dominant logic: Retrospective and extension. Strategic Management Journal, 16(1), 5-14.

12. Reger, R. K., \& Huff, A. S. (1993). Strategic groups: A cognitive perspective. Strategic Management Journal, 14(2), 103-123.

13. Lampel, J., \& Shamsie, J. (2000). Probing the unobtrusive link: Dominant logic and the design of joint ventures at General Electric. Strategic Management Journal, 21, 593-602.

14. Von Krogh, G., \& Roos, J. (1996). A tale of the unfinished. Strategic Management Journal, 17, 729-737.

15. Value creation logic: Describes the focus and means to create value-adding services. Möller, K., Rajala, R., \& Westerlund, M. (2008). Service innovation myopia? A new recipe for client-provider value creation. California Management Review, 50(3), 31-48.

16. Service logic innovation: Conceptualization of the customer (user, buyer, and payer) and the related service innovation. Michel, S., Brown, S. W., \& Gallan, A. S. (2008). Service-logic innovations: How to innovate customers, not products. California Management Review, 50(3), 49-65.

17. Logic of organizational boundaries: Related to organizational boundaries regarding efficiency, power, competence, and identity. Santos, F. M., \& Eisenhardt, K. M. (2005). Organizational boundaries and theories of organization. Organization Science, 16(5), 491-508.

18. Logic of exchange: Conceptualization of value in an exchange relationship. McGinn, K. L., \& Keros, A. T. (2002). Improvisation and the logic of exchange in socially embedded transactions. Administrative Science Quarterly, 47(3), 442-473.

19. Casadesus-Masanell, R., \& Ricart, J. E. (2010). From strategy to business models and onto tactics. Long Range Planning, 43(2), 195-215.

20. Vurro, C., Dacin, M. T., \& Perrini, F. (2010). Institutional antecedents of partnering for social change: How institutional logics shape cross-sector social partnerships. Journal of Business Ethics, 94, 39-53.

21. Bertels, S., \& Lawrence, T. B. (2016). Organizational responses to institutional complexity stemming from emerging logics: The role of individuals. Strategic Organization, 14(4), 336-372.

22. Commercial logic: Structured around selling products and services in the market to produce an economic surplus. Venkataraman, H., Vermeulen, P., Raaijmakers, A., \& Mair, J. (2016). Market meets community: Institutional logics as strategic resources for development work. Organization Studies, 37(5), 709-733.

23. Financial logic: Characterized in terms of profit-maximizing objectives and self-interest. Almandoz, J. (2012). Arriving at the starting line: The impact of community and financial logics on new banking ventures. Academy of Management Journal, 55(6), 1381-1406. 
24. Social welfare logic: Structured around a predominant goal: Making products and services available to address local social needs. Pache, A. C., \& Santos, F. (2013). Inside the hybrid organization: Selective coupling as a response to competing institutional logics. Academy of Management Journal, 56(4), 972-1001.

25. Environmental logic: Concerned with protecting the natural environment and decreasing the firm's impact on natural resources. Dahlmann, F., \& Grosvold, J. (2017). Environmental managers and institutional work: Reconciling tensions of competing institutional logics. Business Ethics Quarterly, 27(2), 263-291.

26. Family logic: Concerned with providing stability and secure income to family members. Belenzon, S., Patacconi, A., \& Zarutskie, R. (2016). Married to the firm? A large-scale investigation of the social context of ownership. Strategic Management Journal, 37(13), 2611-2638.

27. Pache, A. C., \& Santos, F. (2010). When worlds collide: The internal dynamics of organizational responses to conflicting institutional demands. Academy of Management Review, 35(3), 455-476.

28. Almandoz, J. (2014). Founding teams as carriers of competing logics: When institutional forces predict banks' risk exposure. Administrative Science Quarterly, 59(3), 442-473.

29. Koplin, H. T. (1963). The profit maximization assumption. Oxford Economic Papers, 15(2), 130-139.

30. McWilliams, A., \& Siegel, D. (2000). Corporate social responsibility and financial performance: Correlation or misspecification?. Strategic Management Journal, 21(5), 603-609.

31. Collins, J. C., \& Porras, J. I. (1996). Building your company's vision. Harvard Business Review, 74(5), 65.

32. "There is one and only one social responsibility of business: to use its resources and engage in activities designed to increase its profits so long as it stays within the rules of the game, which is to say, engages in open and free competition without deception or fraud." Friedman, M. (1962). Capitalism and freedom. Chicago: University of Chicago Press.

33. For example, Parmar et al. demonstrate simultaneously an increase in selfdetermination for a corporate objective focused on stakeholders and a decrease in self-determination for a corporate objective focused on profits and shareholders. Parmar, B. L., Keevil, A., \& Wicks, A. C. (2019). People and profits: The impact of corporate objectives on employees' need satisfaction at work. Journal of Business Ethics, 154(1), 13.

34. Ready, D. A., \& Truelove, E. (2011). The power of collective ambition. Harvard Business Review.

35. Birkinshaw, J., Foss, N. J., \& Lindenberg, S. (2014). Combining purpose with profits. MIT Sloan Management Review, 55(3), 49. 
36. Grant, R. M. (2016). Contemporary strategy analysis. Hoboken, NJ: John Wiley \& Sons.

37. https://www.blackrock.com/corporate/investor-relations/larry-fink-ceo-letter

38. Bartlett, C. A., \& Ghoshal, S. (1993). Beyond the M-form: Toward a managerial theory of the firm. Strategic Management Journal, 14(S2), 23-46.

39. Porter, M. E., \& Kramer, M. R. (2011). The big idea: Creating shared value. How to reinvent capitalism-And unleash a wave of innovation and growth. Harvard Business Review, 89(1-2).

40. Ismail, S. (2014). Exponential organizations: Why new organizations are ten times better, faster, and cheaper than yours (and what to do about it). New York: Diversion Books.

41. Lok, J. (2010). Institutional logics as identity projects. Academy of Management Journal, 53(6), 1305-1335.

42. Yoffie, D. B., \& Cusumano, M. A. (2015). Strategy rules: Five timeless lessons from Bill Gates, Andy Grove, and Steve Jobs. New York: Harper Business.

43. Ocasio, W., \& Radoynovska, N. (2016). Strategy and commitments to institutional logics: Organizational heterogeneity in business models and governance. Strategic Organization, 14(4), 287-309.

44. Martin, G., Currie, G., Weaver, S., Finn, R., \& McDonald, R. (2017). Institutional complexity and individual responses: Delineating the boundaries of partial autonomy. Organization Studies, 38(1), 103-127.

45. Ricart, J. E., \& Rey, C. (2017, March-April). Strategising for the future. The European Business Review, 7-11.

46. Casadesus-Masanell, R., \& Ricart, J. E. (2011, January). How to design a winning business model. Harvard Business Review, pp. 100-107.

47. Casadesus-Masanell, R., \& Ricart, J. E. (2010). From strategy to business models and onto tactics. Long Range Planning, 43(2), 195-215.

Open Access This chapter is licensed under the terms of the Creative Commons Attribution 4.0 International License (http://creativecommons.org/licenses/by/4.0/), which permits use, sharing, adaptation, distribution and reproduction in any medium or format, as long as you give appropriate credit to the original author(s) and the source, provide a link to the Creative Commons licence and indicate if changes were made.

The images or other third party material in this chapter are included in the chapter's Creative Commons licence, unless indicated otherwise in a credit line to the material. If material is not included in the chapter's Creative Commons licence and your intended use is not permitted by statutory regulation or exceeds the permitted use, you will need to obtain permission directly from the copyright holder.

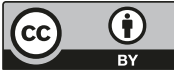

